\title{
Geochemical Stability of Dissolved Mn(III) in the Presence of Pyrophosphate as a Model Ligand: Complexation and Disproportionation
}

Ao Qian ${ }^{1}$,Wen Zhang ${ }^{2}$, Cheng Shi ${ }^{3}$, Chao Pan ${ }^{4}$, Daniel E. Giammar ${ }^{4}$, Songhu Yuan ${ }^{1}$, Hongliang Zhang ${ }^{3}$, Zimeng Wang $^{2,5^{*}}$

${ }^{1}$ State Key Lab of Biogeology and Environmental Geology, China University of Geosciences, Wuhan, Hubei, China

${ }^{2}$ Department of Environmental Science and Engineering, Fudan University, Shanghai, China

${ }^{3}$ Department of Civil and Environmental Engineering, Louisiana State University, Baton Rouge, LA, United State ${ }^{4}$ Department of Energy, Environmental and Chemical Engineering, Washington University in St. Louis, St. Louis, MO, United State

${ }^{5}$ Shanghai Institute of Pollution Control and Ecological Security, Shanghai, China.

* corresponding author: zimengw@ fudan.edu.cn +86-21-31248978

Environmental Science \& Technology

\section{Supporting Information}

Figure S1. Total dissolved Mn over time during disproportionation...................................

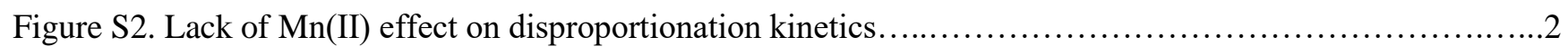

Figure S3. Additional data for the experiments with initially seeded Mn oxides at various concentrations .........3

Figure S4. The lack of destabilization of $\mathrm{Mn}(\mathrm{III})$ at $\mathrm{pH} 7$ when $\delta-\mathrm{MnO}_{2}$ was added at the beginning ............4

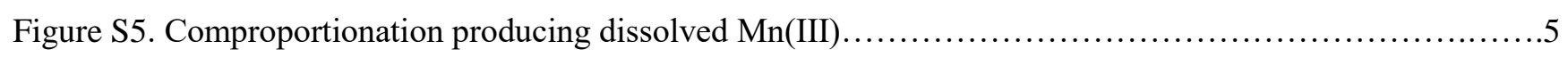

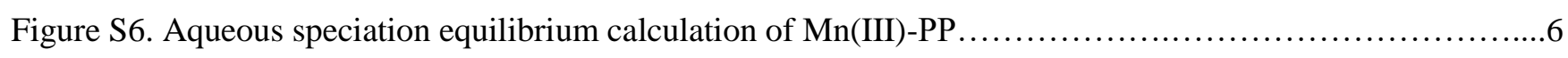

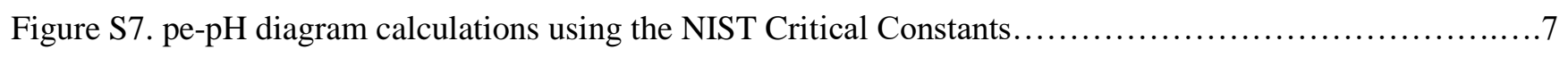

Figure S8. pe-pH diagrams calculations using various sources of equilibrium reactions $\ldots \ldots \ldots \ldots \ldots \ldots \ldots \ldots \ldots$

Figure S9. Model calculated $\mathrm{Mn}(\mathrm{III})$ disproportionation rates through different pathways.....................9

Table S1. Compilation of the equilibrium reactions and constants used to calculate the pe-pH diagrams......10-11 


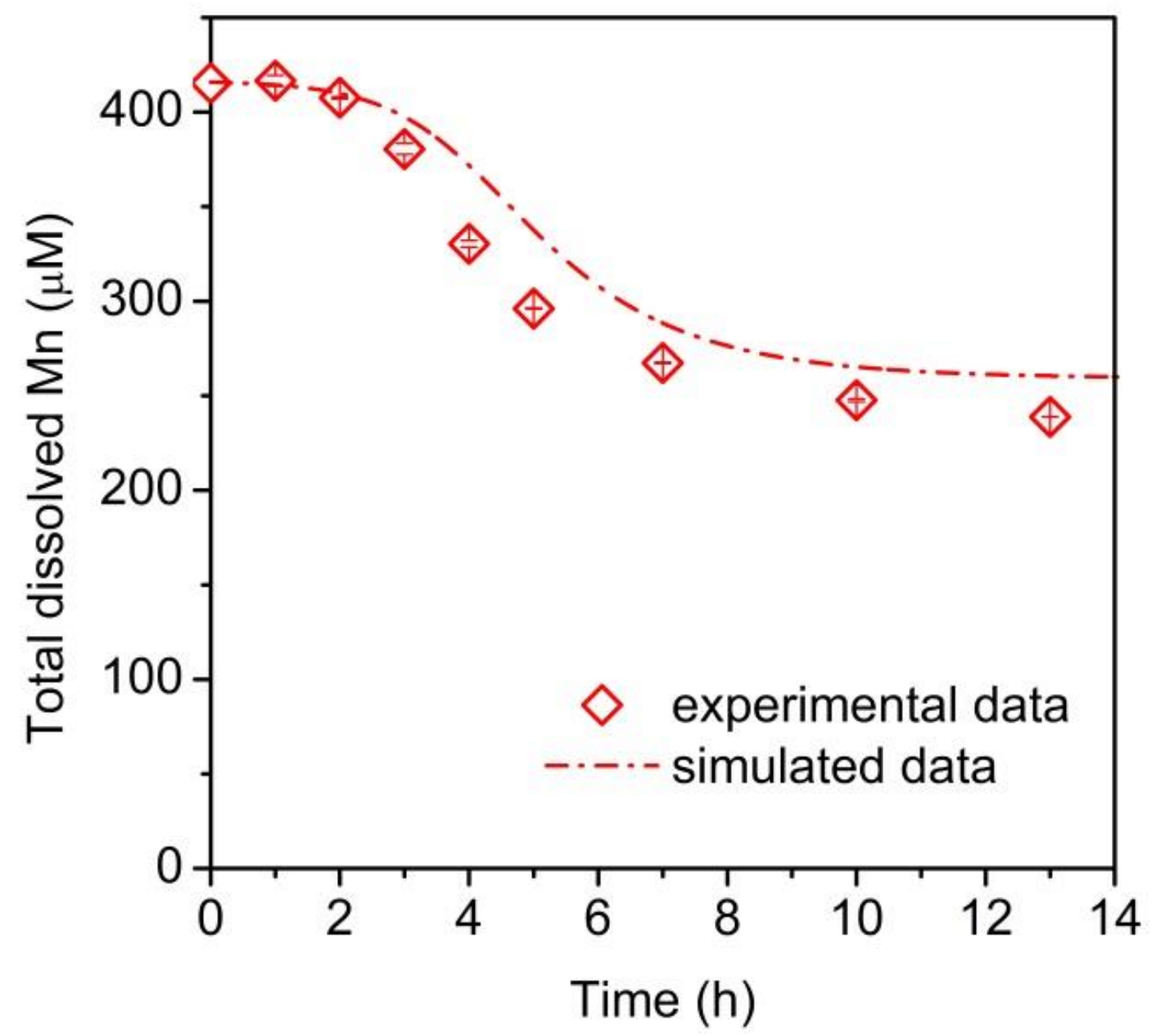

Figure S1 Variation of total dissolved Mn under anoxic conditions at pH 9.0 (Exp. 8 in Table 1). Error bars indicates standard deviation of replicate experiments, which may be smaller than the symbols. 


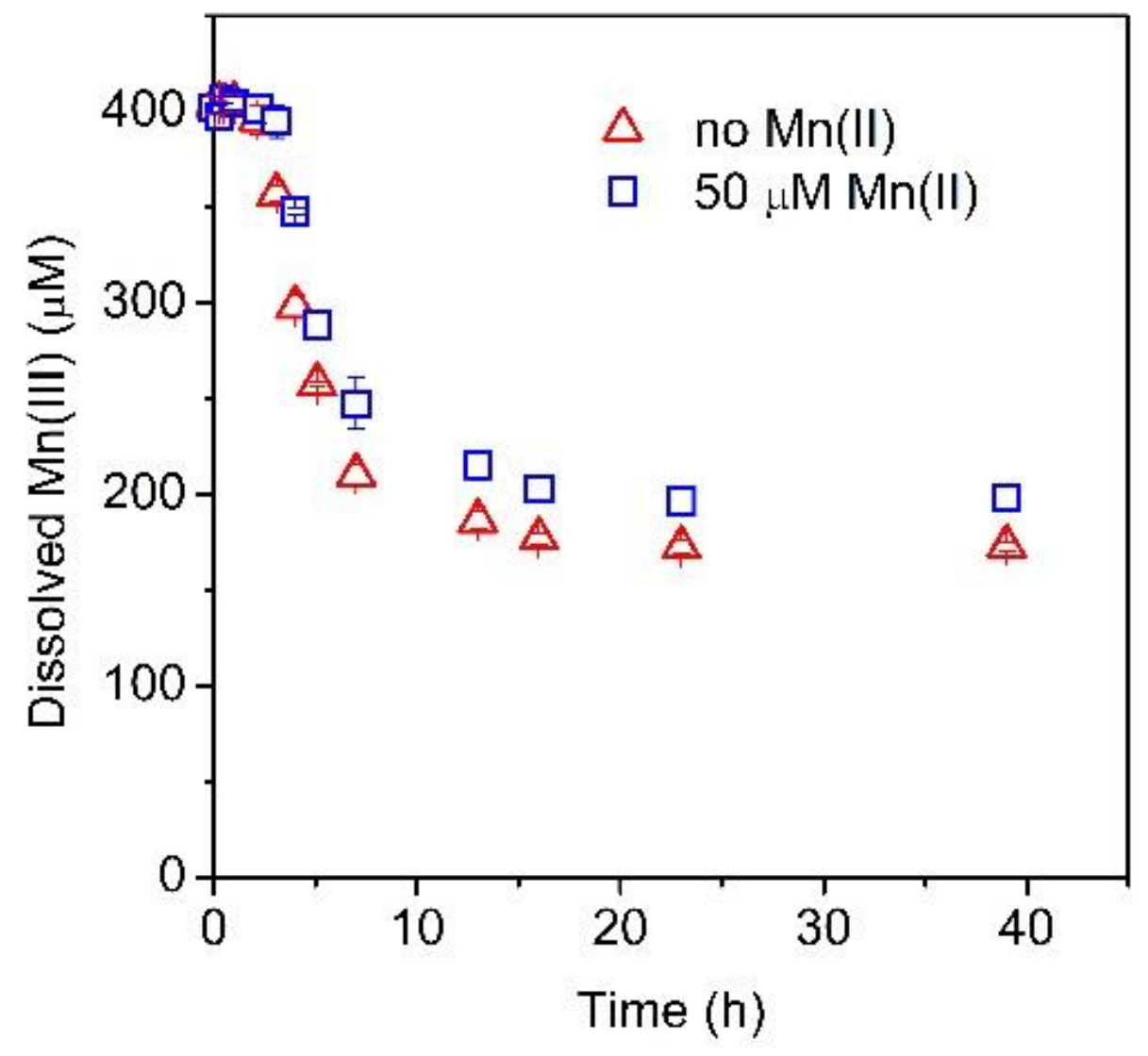

Figure S2 Additional control experiment excluding the effect of $\mathrm{Mn}$ (II) in the autocatalytic behavior of $\mathrm{Mn}$ (III) disproportionation, $\mathrm{Mn}$ (II) $\left(50 \mu \mathrm{M}\right.$ as $\left.\mathrm{MnCl}_{2}\right)$ was added at the beginning of the experiment. The same length of lag phases was observed with and without $\mathrm{Mn}(\mathrm{II})$. The solution $\mathrm{pH}$ was 9 and total PP was $2 \mathrm{mM}$. 

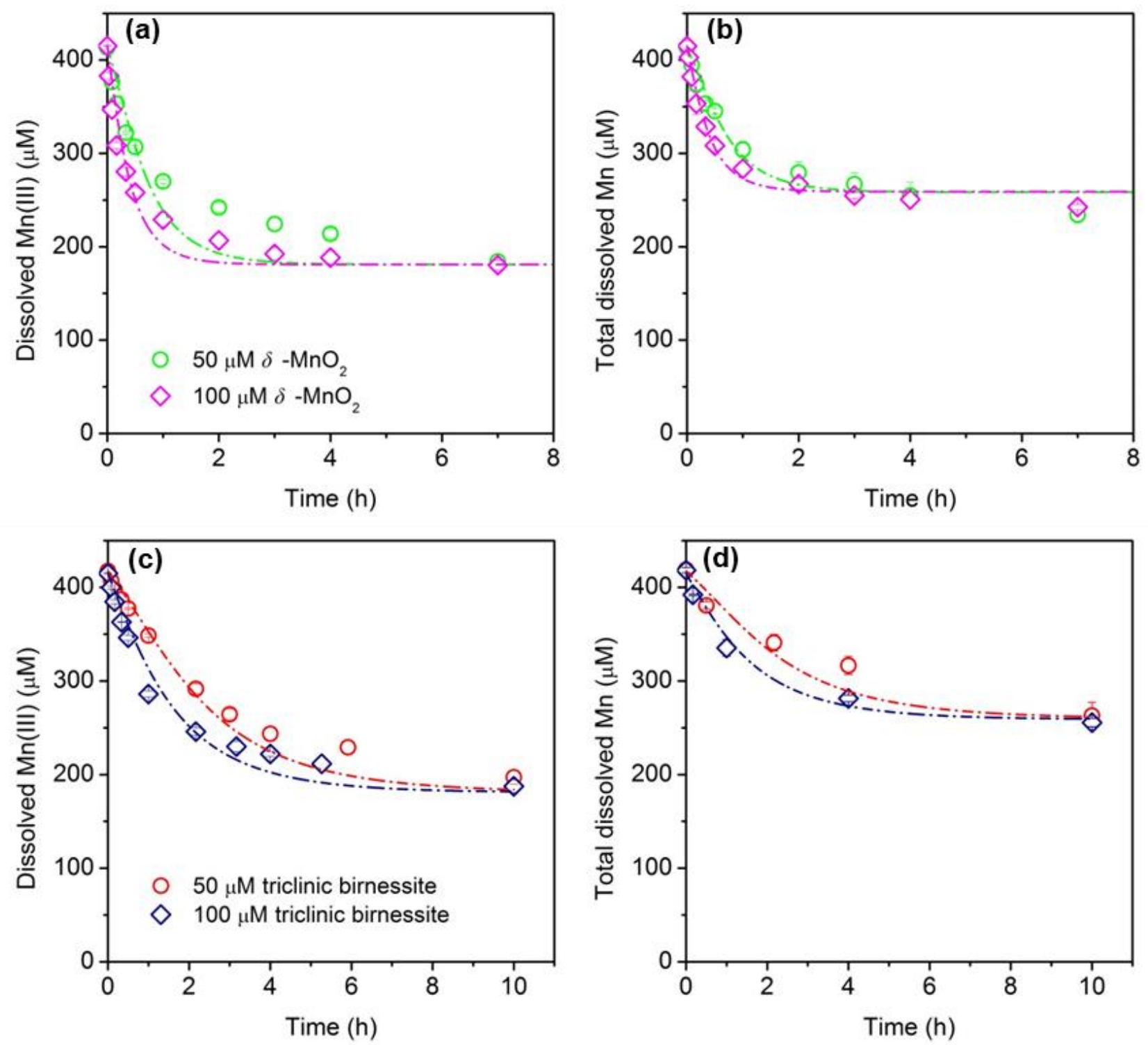

Figure S3. $\mathrm{Mn}(\mathrm{III})$ disproportionation experiments with initially added (a, b) $\delta-\mathrm{MnO}_{2}$ and (c, d) triclinic birnessite at various concentrations (Exp. 10, 11, 13, 14). Experimental data and model simulations are shown as symbol and lines, respectively. Error bars indicates standard deviation of replicate experiments, which may be smaller than the symbols. Note that the models were calibrated only using the kinetic data in the first hour before the solids developed into a mixture of the two oxides, which explained the poor performance of the model for the $\delta-\mathrm{MnO}_{2}$ case (details in texts). 


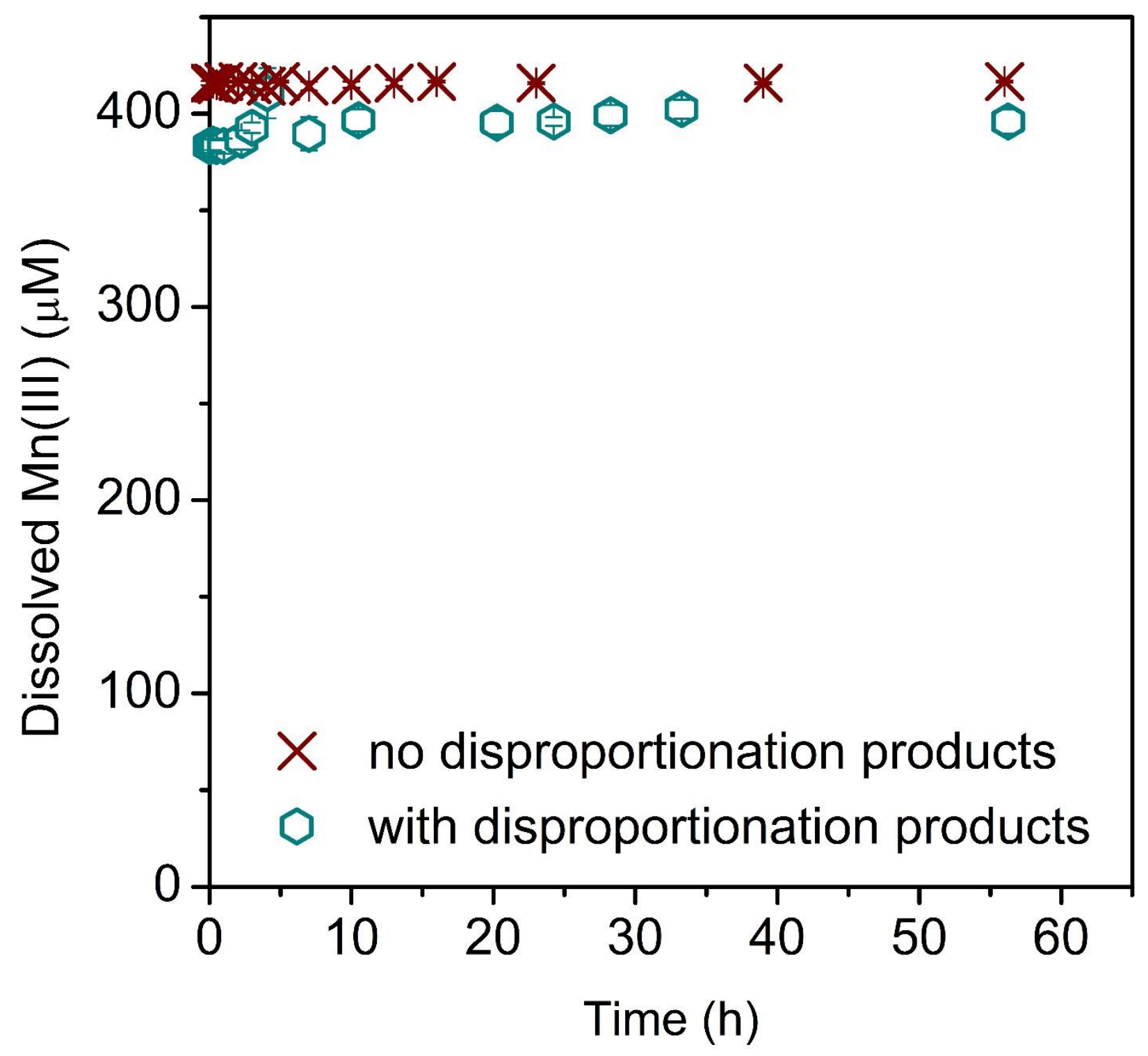

Figure S4. The lack of destabilization of $\mathrm{Mn}(\mathrm{III})$ at $\mathrm{pH} 7$ when the ex-situ obtained solids from disproportionation was added at the beginning. The estimated amount of solid added was about $133 \mu \mathrm{M}$ (normalized to $\mathrm{Mn}$ atoms) based on the mass conservation for a separate experiment conducted at $\mathrm{pH} 9$ (Exp. 8). The Total PP was $2 \mathrm{mM}$ for both experiments. 


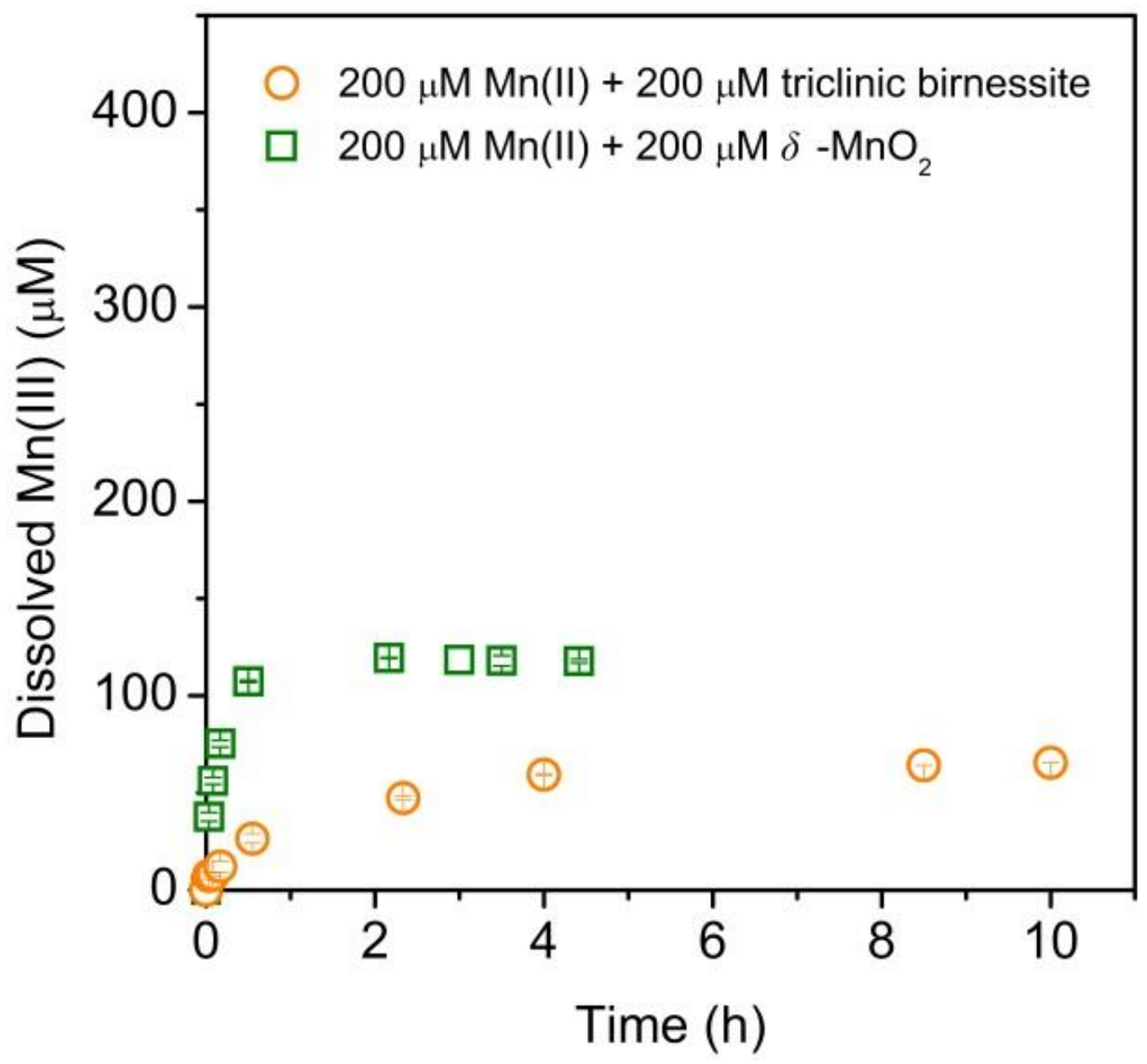

Figure S5. Production of dissolved Mn(III) complexes from comproportionation of $\mathrm{Mn}$ (II) and Mn oxides (Exp. 15 and 16) in the presence of pyrophosphate. 

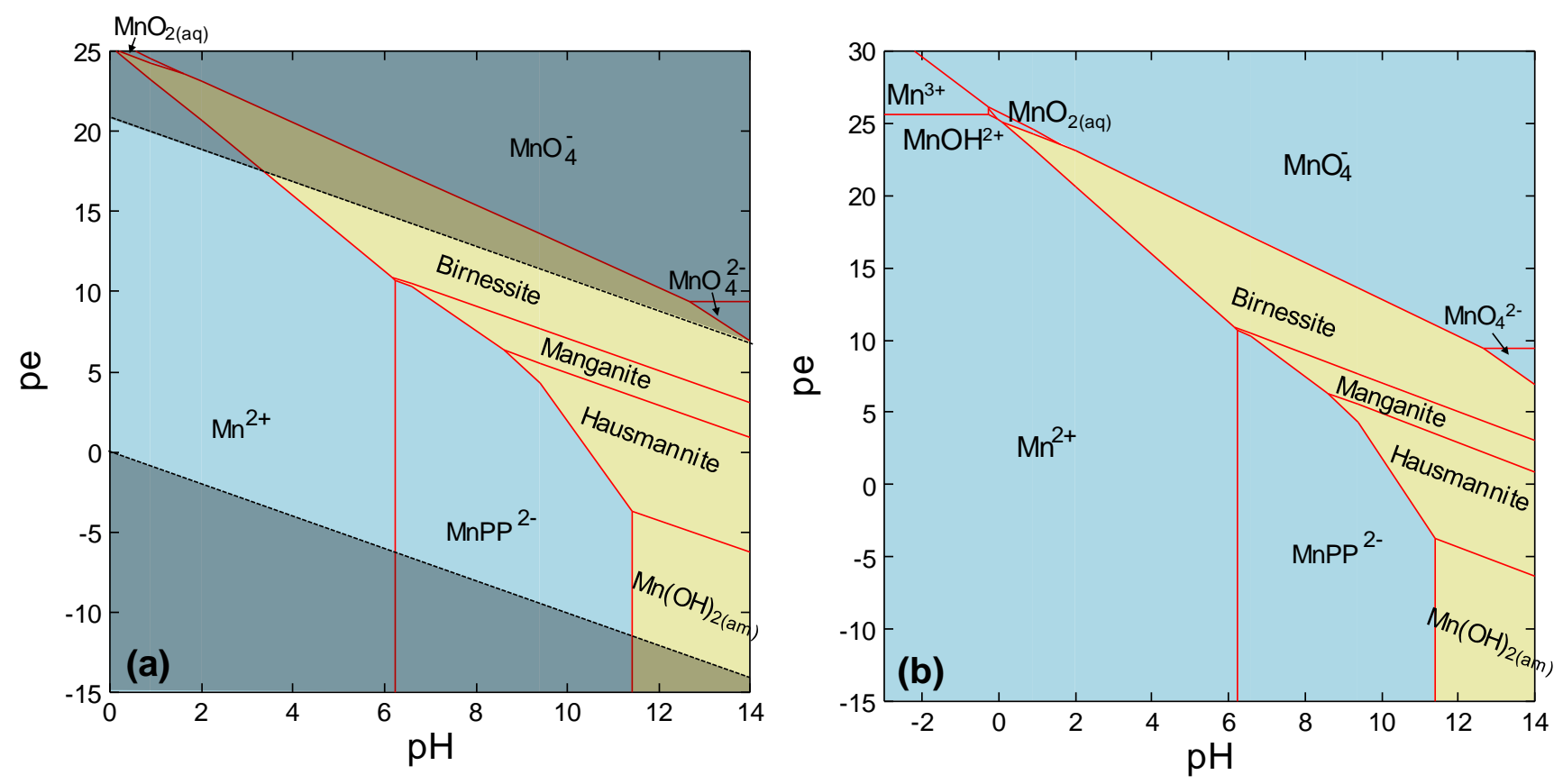

Figure S6. pE-pH diagram of $\mathrm{Mn}$ in the presence of $\mathrm{Mn}$ (III)-complexing ligands using the equilibrium reactions and constant in the NIST database. (details in Table S1). The shaded areas above and below the dash lines indicate conditions beyond the stability regime of water. The total concentrations of $\mathrm{Mn}$ (III) and PP were 0.1 and $1 \mathrm{mM}$ respectively. Panel $\mathrm{b}$ extended the $\mathrm{y}$ axis to $\mathrm{pe}=30$, allowing to the see the presence of $\mathrm{Mn}$ (III) species. The species and equilibrium constants retrieved from the NIST database were not able to predict the geochemical stability of $\mathrm{Mn}(\mathrm{III})$. 

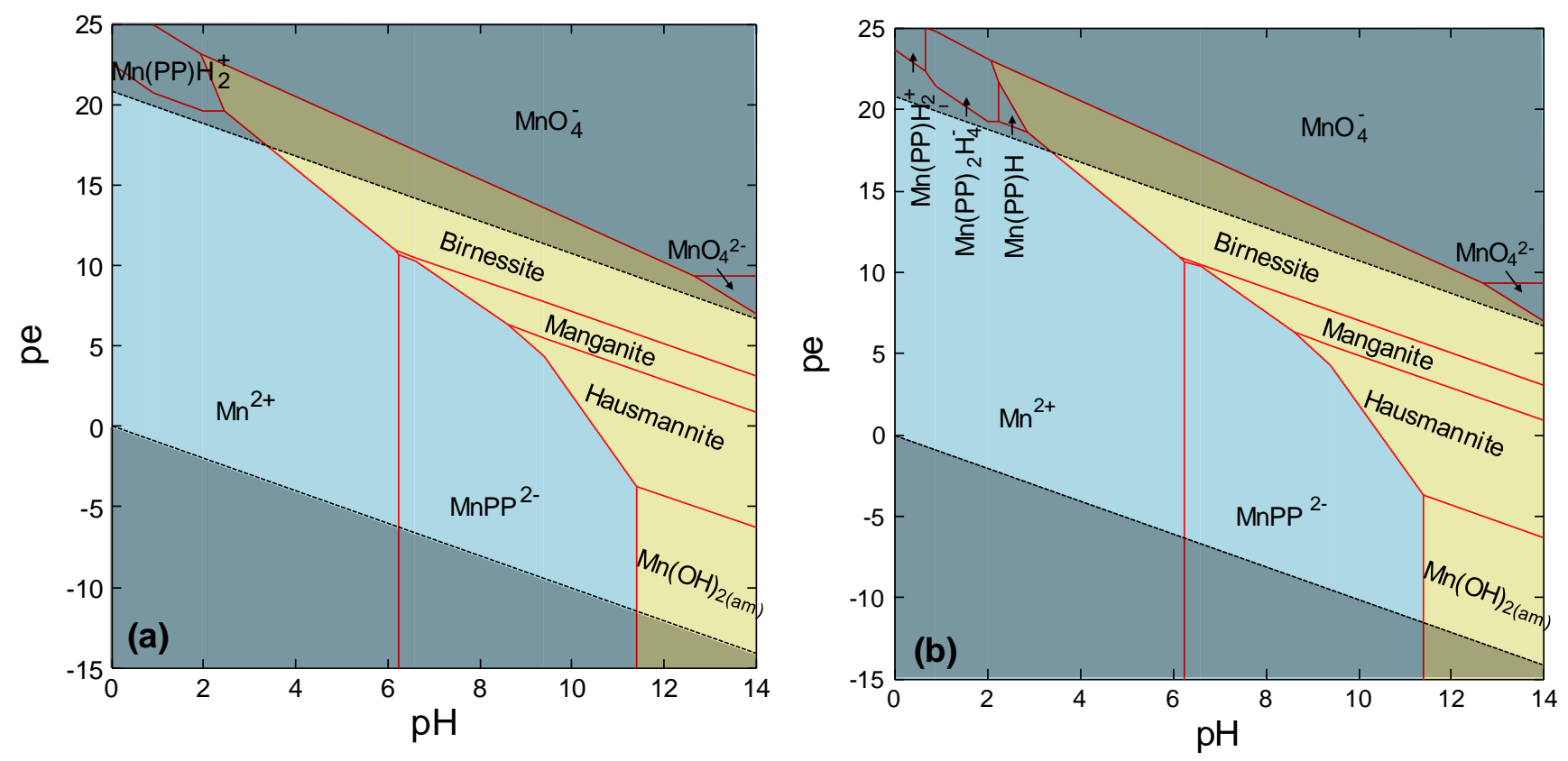

Figure S7. pE-pH diagrams of $\mathrm{Mn}$ in the presence of $\mathrm{Mn}$ (III)-complexing ligands using the equilibrium reaction and constants in (a) Bogdanovich et al and (b) Ciavatta and Palombari. (details in Table S1). The shaded areas above and below the dash lines indicate conditions beyond the stability regime of water. The total concentrations of $\mathrm{Mn}$ (III) and PP were 0.1 and $1 \mathrm{mM}$ respectively. Those constants were originally from the studies conducted at extremely acidic conditions, and their thermodynamic predominance were predicted to occur at low $\mathrm{pH}$ but were above the stability regime of water. 


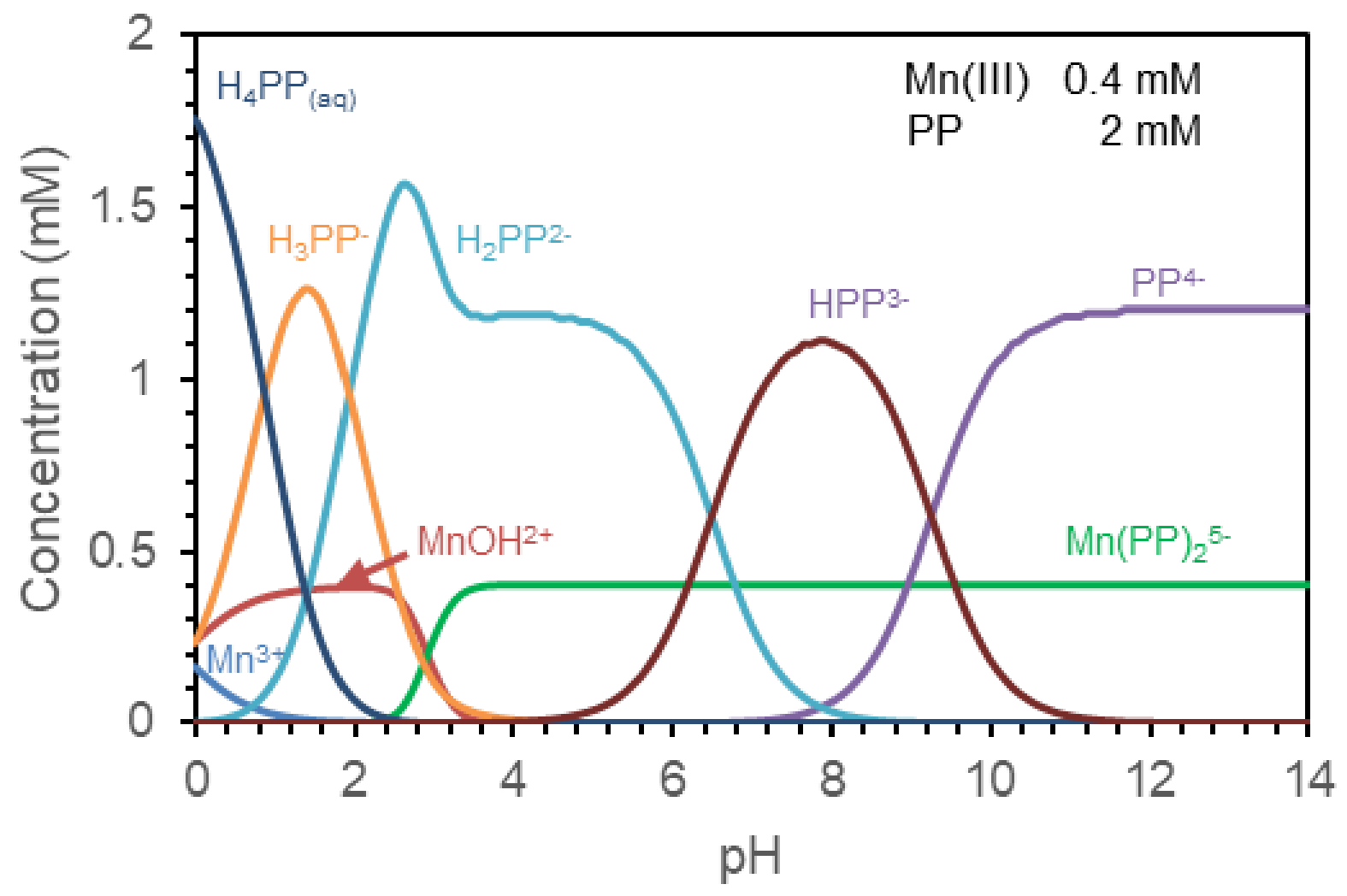

Figure S8. Aqueous speciation equilibrium of $0.4 \mathrm{mM} \mathrm{Mn}(\mathrm{III})$ and $2 \mathrm{mM}$ PP at various $\mathrm{pH}$. Redox chemistry and solid precipitation were disabled in the calculation. The stability constant $(\log \mathrm{K})$ for $\mathrm{Mn}(\mathrm{PP})_{2}{ }^{5-}$ used in the calculation was 28.9, as calibrated using the present disproportionation results. If the Gordienko et al. constant 30.9 was used, then the $\mathrm{pH}$ required to decomplex the $\mathrm{Mn}$ (III)-PP would be even lower than $\mathrm{pH} 3$, confirming our attribution of the $\mathrm{Mn}(\mathrm{III})$ loss to disproportionation. 

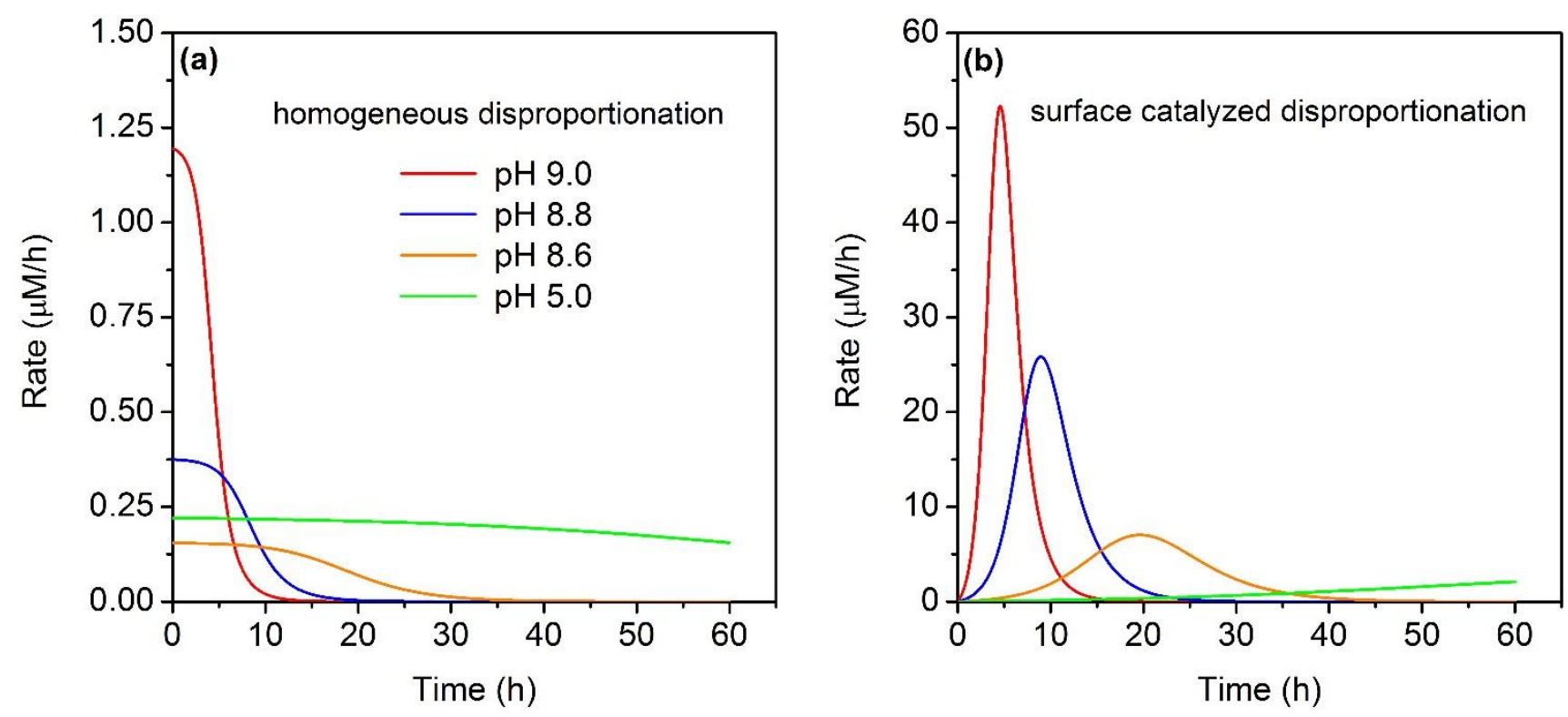

Figure S9. Model calculated Mn(III) disproportionation rates through (a) homogenous and (b) surface catalyzed pathways. Detailed experimental conditions are presented in Table 1. 
Table S1. Equilibrium reaction and constants relevant to the Mn thermodynamic calculations (note the direction how the reactions were written)

\begin{tabular}{|c|c|c|c|}
\hline Species & Equilibrium Reactions & $\log K$ & Reference \\
\hline $\mathrm{Mn}^{2+}$ & $\mathrm{Mn}^{2+}=\mathrm{Mn}^{2+}$ & 0 & GWB Thermo_Ladder.dat \\
\hline $\mathrm{Mn}^{3+}$ & $\mathrm{Mn}^{3+}+0.5 \mathrm{H}_{2} \mathrm{O}=\mathrm{Mn}^{2+}+\mathrm{H}^{+}+0.25 \mathrm{O}_{2 \text { (aq) }}$ & 4.0811 & GWB Thermo_Ladder.dat \\
\hline $\mathrm{MnO}_{4}^{-}$ & $\mathrm{MnO}_{4}^{-}+3 \mathrm{H}^{+}=\mathrm{Mn}^{2+}+1.25 \mathrm{O}_{2}(\mathrm{aq})+1.5 \mathrm{H}_{2} \mathrm{O}$ & 20.2928 & GWB Thermo_Ladder.dat \\
\hline $\mathrm{MnO}_{4}^{2-}$ & $\mathrm{MnO}_{4}^{2-}+4 \mathrm{H}^{+}=\mathrm{Mn}^{2+}+\mathrm{O}_{2(\text { aq })}+2 \mathrm{H}_{2} \mathrm{O}$ & 32.4103 & GWB Thermo_Ladder.dat \\
\hline $\mathrm{Mn}(\mathrm{OH})_{2 \text { (aq) }}$ & $\mathrm{Mn}(\mathrm{OH})_{2}+2 \mathrm{H}^{+}=\mathrm{Mn}^{2+}+2 \mathrm{H}_{2} \mathrm{O}$ & 22.1962 & GWB Thermo_Ladder.dat \\
\hline $\mathrm{Mn}(\mathrm{OH})_{3}^{-}$ & $\mathrm{Mn}(\mathrm{OH})_{3}{ }^{-}+3 \mathrm{H}^{+}=\mathrm{Mn}^{2+}+3 \mathrm{H} 2 \mathrm{O}$ & 34.2142 & GWB Thermo_Ladder.dat \\
\hline $\mathrm{Mn}(\mathrm{OH})_{4}^{2-}$ & $\mathrm{Mn}(\mathrm{OH})_{4}{ }^{2-}+4 \mathrm{H}^{+}=\mathrm{Mn}^{2+}+4 \mathrm{H}_{2} \mathrm{O}$ & 48.292 & GWB Thermo_Ladder.dat \\
\hline $\mathrm{Mn}_{2}(\mathrm{OH})_{3}^{+}$ & $\mathrm{Mn}_{2}(\mathrm{OH})_{3}{ }^{+}+3 \mathrm{H}^{+}=2 \mathrm{Mn}^{2+}+3 \mathrm{H}_{2} \mathrm{O}$ & 23.8953 & GWB Thermo_Ladder.dat \\
\hline $\mathrm{Mn}_{2} \mathrm{OH}^{3+}$ & $\mathrm{Mn}_{2} \mathrm{OH}^{3+}+\mathrm{H}^{+}=2 \mathrm{Mn}^{2+}+\mathrm{H}_{2} \mathrm{O}$ & 10.555 & GWB Thermo_Ladder.dat \\
\hline $\mathrm{MnOH}^{+}$ & $\mathrm{MnOH}^{+}+\mathrm{H}^{+}=\mathrm{Mn}^{2+}+\mathrm{H}_{2} \mathrm{O}$ & 10.5887 & GWB Thermo_Ladder.dat \\
\hline $\mathrm{MnOH}^{2+}$ & $\mathrm{MnOH}^{2+}+\mathrm{H}^{+}=\mathrm{Mn}^{3+}+\mathrm{H}_{2} \mathrm{O}$ & -0.27 & GWB Thermo_Ladder.dat \\
\hline $\mathrm{Mn}(\mathrm{OH})_{3(\mathrm{c})}$ & $\mathrm{Mn}(\mathrm{OH})_{3}+3 \mathrm{H}^{+}=\mathrm{Mn}^{3+}+3 \mathrm{H}_{2} \mathrm{O}$ & 6.3465 & GWB Thermo_Ladder.dat \\
\hline $\mathrm{MnPP}^{2-}$ & $\mathrm{MnPP}^{2-}=\mathrm{Mn}^{2+}+\mathrm{PP}^{4-}$ & -6.51 & $\begin{array}{l}\text { Bilinski, H. Polyhedron 1983, } 2 \text { (5), } \\
\text { 353-358 }\end{array}$ \\
\hline $\begin{array}{c}\text { Birnessite }_{(a q)} \\
\left(\mathrm{Mn}_{8} \mathrm{O}_{14} \cdot 5 \mathrm{H}_{2} \mathrm{O}\right)\end{array}$ & Birnessite $_{(\mathrm{aq})}+16 \mathrm{H}^{+}=8 \mathrm{Mn}^{2+}+3 \mathrm{O}_{2(\mathrm{aq})}+13 \mathrm{H}_{2} \mathrm{O}$ & $22.6975^{\mathrm{a}}$ & GWB Thermo_Ladder.dat \\
\hline Birnessite & Birnessite $=$ Birnessite $(\mathrm{aq})$ & $-9^{\mathrm{a}}$ & GWB Thermo_Ladder.dat \\
\hline $\mathrm{MnO}_{2 \text { (aq) }}$ & $\mathrm{MnO}_{2(\mathrm{aq})}+2 \mathrm{H}^{+}=\mathrm{Mn}^{2+}+0.5 \mathrm{O}_{2 \text { (aq) }}+\mathrm{H}_{2} \mathrm{O}$ & $7.5622^{\mathrm{b}}$ & GWB Thermo_Ladder.dat \\
\hline Pyrolusite & Pyrolusite $=\mathrm{MnO}_{2(\mathrm{aq})}$ & $-9^{b}$ & GWB Thermo_Ladder.dat \\
\hline $\begin{array}{l}\text { Bixbyite } \\
\left(\mathrm{Mn}_{2} \mathrm{O}_{3}\right)\end{array}$ & Bixbyite $+6 \mathrm{H}^{+}=2 \mathrm{Mn}^{3+}+3 \mathrm{H}_{2} \mathrm{O}$ & -0.9684 & GWB Thermo_Ladder.dat \\
\hline $\begin{array}{l}\text { Hausmannite } \\
\left(\mathrm{Mn}_{3} \mathrm{O}_{4}\right)\end{array}$ & Hausmannite $+8 \mathrm{H}^{+}=\mathrm{Mn}^{2+}+2 \mathrm{Mn}^{3+}+4 \mathrm{H}_{2} \mathrm{O}$ & 10.1554 & GWB Thermo_Ladder.dat \\
\hline $\begin{array}{l}\text { Manganite } \\
(\mathrm{MnOOH})\end{array}$ & Manganite $+3 \mathrm{H}^{+}=\mathrm{Mn}^{3+}+2 \mathrm{H}_{2} \mathrm{O}$ & -0.1668 & GWB Thermo_Ladder.dat \\
\hline $\begin{array}{l}\text { Manganosite } \\
(\mathrm{MnO})\end{array}$ & Manganosite $+2 \mathrm{H}^{+}=\mathrm{Mn}^{2+}+\mathrm{H}_{2} \mathrm{O}$ & 17.9259 & GWB Thermo_Ladder.dat \\
\hline
\end{tabular}




\begin{tabular}{|c|c|c|c|}
\hline $\mathrm{Mn}(\mathrm{OH})_{2}(\mathrm{am})$ & $\mathrm{Mn}(\mathrm{OH})_{2}+2 \mathrm{H}^{+}=\mathrm{Mn}^{2+}+2 \mathrm{H}_{2} \mathrm{O}$ & 15.2989 & GWB Thermo_Ladder.dat \\
\hline $\begin{array}{c}\text { Todorokite } \\
\left(\mathrm{Mn}_{7} \mathrm{O}_{12} \bullet 3 \mathrm{H}_{2} \mathrm{O}\right)\end{array}$ & Todorokite $+12 \mathrm{H}^{+}=4 \mathrm{Mn}^{3+}+3 \mathrm{MnO}_{2}+9 \mathrm{H}_{2} \mathrm{O}$ & -27.9486 & GWB Thermo_Ladder.dat \\
\hline MnHPP & $\mathrm{MnHPP}=\mathrm{Mn}^{3+}+\mathrm{H}^{+}+\mathrm{PP}^{4-}$ & -21.1 & NIST Critical Constants \\
\hline $\mathrm{MnH}_{2} \mathrm{PP}^{+}$ & $\mathrm{MnH}_{2} \mathrm{PP}^{+}=\mathrm{Mn}^{3+}+2 \mathrm{H}^{+}+\mathrm{PP}^{4-}$ & -25 & Bogdanovich et al 1982 \\
\hline MnHPP & $\mathrm{MnHPP}=\mathrm{Mn}^{3+}+\mathrm{H}^{+}+\mathrm{PP}^{4-}$ & -23.1 & Ciavatta and Palombari, 1983 \\
\hline $\mathrm{MnH}_{2} \mathrm{PP}^{+}$ & $\mathrm{MnH}_{2} \mathrm{PP}^{+}=\mathrm{Mn}^{3+}+2 \mathrm{H}^{+}+\mathrm{PP}^{4-}$ & -23.76 & Ciavatta and Palombari, 1983 \\
\hline $\mathrm{MnH}_{4}(\mathrm{PP})_{2}^{-}$ & $\mathrm{MnH}_{4}(\mathrm{PP})_{2}^{-}=\mathrm{Mn}^{3+}+4 \mathrm{H}^{+}+2 \mathrm{PP}^{4-}$ & -44.34 & Ciavatta and Palombari, 1983 \\
\hline $\mathrm{MnH}_{5}(\mathrm{PP})_{2}$ & $\mathrm{MnH}_{5}(\mathrm{PP})_{2}=\mathrm{Mn}^{3+}+5 \mathrm{H}^{+}+2 \mathrm{PP}^{4-}$ & -44.56 & Ciavatta and Palombari, 1983 \\
\hline $\mathrm{MnPP}^{-}$ & $\mathrm{MnPP}^{-}=\mathrm{Mn}^{3+}+\mathrm{PP}^{4-}$ & -16.7 & Gordienko et al. 1970 \\
\hline $\mathrm{Mn}(\mathrm{PP})_{2}{ }^{5-}$ & $\mathrm{Mn}(\mathrm{PP})_{2}{ }^{5-}=\mathrm{Mn}^{3+}+2 \mathrm{PP}^{4-}$ & -30.9 & Gordienko et al. 1970 \\
\hline $\mathrm{MnH}_{2} \mathrm{PP}^{+}$ & $\mathrm{MnH}_{2} \mathrm{PP}^{+}=\mathrm{Mn}^{3+}+2 \mathrm{H}^{+}+\mathrm{PP}^{4-}$ & -21.1 & Gordienko et al. 1970 \\
\hline $\mathrm{MnH}_{4}(\mathrm{PP})_{2}^{-}$ & $\mathrm{MnH}_{4}(\mathrm{PP})_{2}^{-}=\mathrm{Mn}^{3+}+4 \mathrm{H}^{+}+2 \mathrm{PP}^{4-}$ & -40.4 & Gordienko et al. 1970 \\
\hline $\mathrm{MnH}_{6}(\mathrm{PP})_{3}{ }^{3-}$ & $\mathrm{MnH}_{6}(\mathrm{PP})_{3}^{3-}=\mathrm{Mn}^{3+}+6 \mathrm{H}^{+}+3 \mathrm{PP}^{4-}$ & -59.2 & Gordienko et al. 1970 \\
\hline
\end{tabular}

a. Fictive $\mathrm{Mn}(\mathrm{III})-\mathrm{Mn}(\mathrm{IV})$ species with activity of $10^{-9}$ in equilibrium with birnessite:

Birnessite $+16 \mathrm{H}^{+}=8 \mathrm{Mn}^{2+}+3 \mathrm{O}_{2}(\mathrm{aq})+13 \mathrm{H}_{2} \mathrm{O} \log \mathrm{K}=11.6975$

Birnessite $=$ Birn $(\mathrm{aq}) \quad \log \mathrm{K}=-9$

$\operatorname{Birn}(\mathrm{aq})+16 \mathrm{H}^{+}=8 \mathrm{Mn}^{2+}+3 \mathrm{O}_{2}(\mathrm{aq})+13 \mathrm{H}_{2} \mathrm{O} \quad \log \mathrm{K}=22.6975$

b. Fictive $\mathrm{Mn}(\mathrm{IV})$ species with activity of $10^{-9}$ in equilibrium with pyrolusite:

Pyrolusite $+2 \mathrm{H}^{+}=\mathrm{Mn}^{2+}+1 / 2 \mathrm{O}_{2}(\mathrm{aq})+\mathrm{H}_{2} \mathrm{O} \quad \log \mathrm{K}=-1.4378$

Pyrolusite $=\mathrm{MnO}_{2 \text { (aq) }} \quad \log \mathrm{K}=-9$

$\mathrm{MnO}_{2}(\mathrm{aq})+2 \mathrm{H}^{+}=\mathrm{Mn}^{2+}+1 / 2 \mathrm{O}_{2}(\mathrm{aq})+\mathrm{H}_{2} \mathrm{O} \quad \log \mathrm{K}=7.5622$

Other critical description of the Thermo_Ladder database (adapted and modified from the file header)

activity model: debye-huckel

File thermo_ladder.dat is the LLNL thermo.dat database modified to allow decoupling of the Mn(III) and Mn(IV) redox states. Specifically:

(1) the $\mathrm{Mn}^{+++}$redox species has been imported from

thermo.com.v8.r6+.dat.

(2) a fictive $\mathrm{Mn}(\mathrm{IV})$ redox specie $\mathrm{MnO}_{2}$ (aq) has been created, with a stability set to give an activity of $10^{-9}$ in equilibrium with pyrolusite.

(3) reactions for the $\mathrm{Mn}(\mathrm{III})$ - and $\mathrm{Mn}(\mathrm{IV})$-bearing minerals have been rebalanced in terms of the new redox species.

(4) there is a second fictive redox species of mixed $\mathrm{Mn}(\mathrm{III})-\mathrm{Mn}(\mathrm{IV})$ valance state, for decoupling Birnessite.

(5) The pKa constants of pyrophosphates were from McElroy, W.D.; Glass, B. Phosphorus Metabolism, Vol. I, Baltimore, Johns Hopkins University Press, 1951. 